\title{
Factors influencing seedling recruitment in a critically endangered pitcher plant, Sarracenia rubra ssp. alabamensis
}

\author{
J. D. Chesser, J. S. Brewer* \\ Department of Biology, University of Mississippi, PO Box 1848, University, Mississippi 38677-1848, USA
}

\begin{abstract}
Sarracenia rubra ssp. alabamensis is a critically endangered pitcher plant endemic to central Alabama (USA); efforts have been made to protect the remaining populations, including the use of prescribed fire and thinning to restore the savanna-like structure that historically characterized its habitat and to promote the beneficial effects of fire on seedling establishment observed in other pitcher plant species. Despite these efforts, seedling recruitment remains very low within the largest population of $S$. rubra ssp. alabamensis. We considered the possibility that other factors such as germinability, seed removal (by predators or dispersal agents), and inadequate soil moisture were reducing or preventing seedling recruitment. We report the results of laboratory and field experiments investigating factors limiting seedling recruitment and establishment in the 2 largest remaining populations, which were observed at sites that differed in soil moisture, fire management, and the abundance of sphagnum moss. Seedling recruitment was higher at the wet unmanaged site than at the dry, fire-managed site. The major contributing factors to site differences in recruitment were a greater abundance of safe sites for germination (specifically, patches of sphagnum) and lower seedling mortality at the wet unmanaged site as a result of higher soil moisture. We recommend that land managers shift some of their attention to this and other wet sites and seek permission to increase population density and restore fire at these sites.
\end{abstract}

KEY WORDS: Fire suppression $\cdot$ Safe site $\cdot$ Soil moisture $\cdot$ Seepage bog $\cdot$ Restoration $\cdot$ Sphagnum Pinus palustris • Fall Line Hills

\section{INTRODUCTION}

Seedling recruitment is an increasingly important means of regeneration for plants in the face of rapid climate change and habitat destruction. Species that are unable to colonize new sites or adapt to changing environmental conditions will eventually become extinct. This problem is particularly acute for endangered, long-lived perennial plants that maintain populations primarily through vegetative reproduction and genet survival (Brewer 2001, Ellis et al. 2007). Despite low rates of seedling establishment typically observed in long-lived clonal perennial plants, experimental establishment of new populations of such species is likely to be easier and less destructive if done using seeds than by transplanting adults. The long-term viability of metapopulations of perennial plants depends not only on their ability to maintain local populations via clonal growth but also on their ability to establish at new sites via seedling recruitment (Menges 1990, Ellis et al. 2007).

Although many factors (genetic and environmental) affect seedling recruitment, seed supply and the availability of safe sites for seed germination and seedling establishment are among the most important (Harper 1977). Many fire-dependent plant species exhibit increased seedling recruitment following fire (Zammit \& Westoby 1987, Keeley 1991, Menges 1995, Brewer 
1999, Carrington 1999, Lesica 1999). Such increases can result from increased seed or seedling supply due to increased flowering or reduced predation or herbivory (O'Dowd \& Gill 1984, Brewer \& Platt 1994, Kirkman et al. 1998) and/or improved environmental conditions for seedlings after fire (Christensen \& Muller 1975, Zammit \& Westoby 1987, 1988, Brewer 1999). However, the benefits of post-fire increases in seedling recruitment depend strongly on life history (Zammit \& Westoby 1987, Keeley 1991, Brewer 2001, Brewer et al. 2009), and can in some cases be abrogated by increased seed predation or other environmental factors that negatively affect seeds or seedlings (Lamont et al. 1993, Denham 2008). Hence, elucidating the causes of differences in seedling recruitment between burned and unburned sites requires taking into account a species' life history and site-related differences other than fire, such as seed predation and the availability of safe sites for ger-

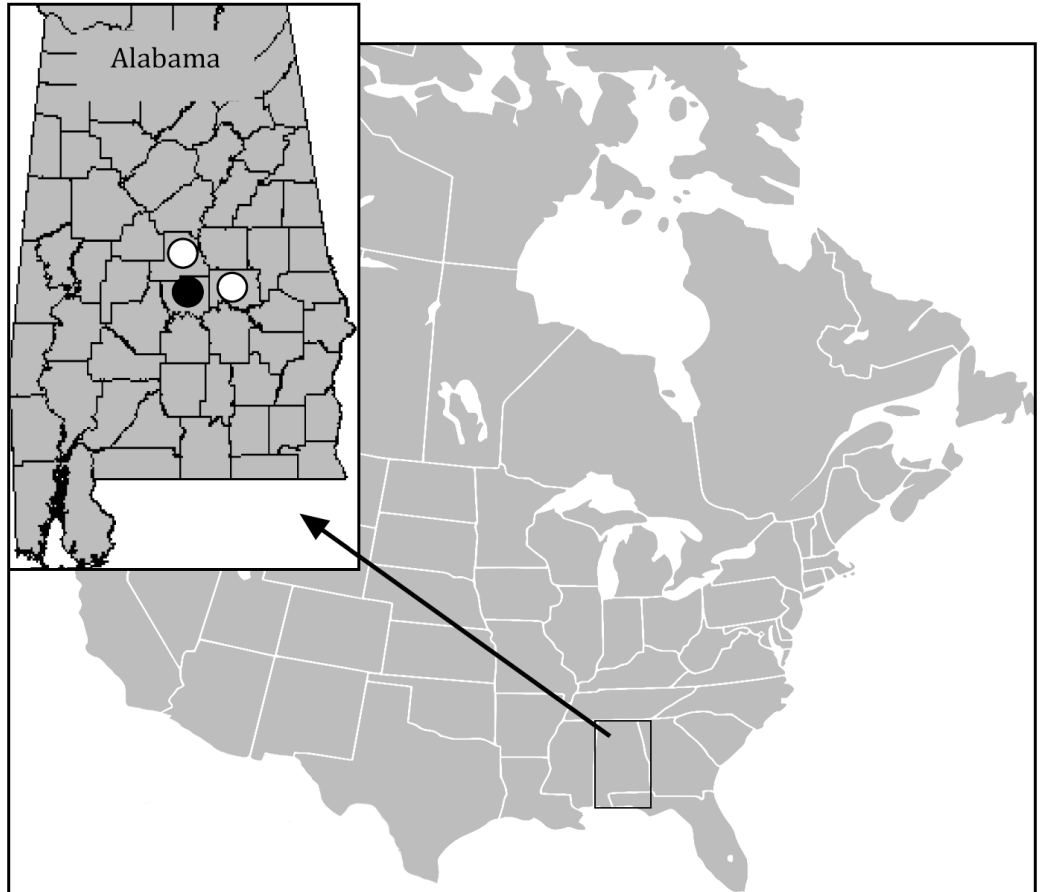

Fig. 1. Sarracenia rubra ssp. alabamensis. Location of the remaining known populations in Alabama, USA (arrow). The filled circle (inset) indicates Autauga County, where both focal sites were located. The open circles indicate the other 2 counties in which populations are known to have occurred mination and seedling survival.

Sarracenia rubra ssp. alabamensis (Case \& Case 1974, Schnell 2002), the Alabama canebrake pitcher plant, is a long-lived, rhizomatous perennial carnivorous plant endemic to Autauga, Chilton, and Elmore Counties in the Coosa River drainage of central Alabama, USA (Fig. 1; US Fish and Wildlife Service [USFWS] 1992). Historically, the species was associated with seepage areas within fire-maintained longleaf pine Pinus palustris savannas (Harper 1922). Because all known extant populations of $S$. rubra ssp. alabamensis are on privately owned land, the USFWS is currently working with landowners in an effort to manage and protect the populations on their respective properties. Conservation easements have been granted for 2 of the larger sites (USFWS 1992). Authorities are in the process of working out agreements with other landowners as well. The Nature Conservancy (TNC) has bought land containing a few of the populations, including what currently appears to be the largest remaining population, located within the Roberta Case Pine Hills Preserve.

To restore the historical fire regime of those longleaf pine seepage areas that currently support populations of Sarracenia rubra ssp. alabamensis, recovery plans from both USFWS and TNC include some provision for removing woody vegetation via prescribed burning and/or cutting various off-site species of mesophytic trees that have encroached upon the habitat as a result of fire suppression. Previous work has shown, however, that seedling recruitment is very low in this species and apparently not increased by fire or thinning (Brewer 2005). The apparent lack of responsiveness of $S$. rubra ssp. alabamensis seedling recruitment to fire at the Pine Hills site contrasts sharply with that of $S$. alata in wet pine savannas along the US Gulf coast. Previous studies have shown that seedling densities of this species increase significantly following winter fires (Barker \& Williamson 1988, Brewer 2001), apparently due to increased seedling survival following firemediated reductions in surface leaf litter (J. S. Brewer unpubl. data).

The lack of seedling recruitment at the fire-managed Pine Hills site could be caused by a variety of factors including genetic factors (e.g. inbreeding depression) and environmental factors such as seed predation and/or loss from washing or deep burial, desiccation, and inadequate stratification (cold treatment) during warm winters. Preliminary experiments have revealed that seed set is high, as is seed germinability $(\sim 73 \%)$, which is significantly higher than the levels observed in small, isolated populations of Sarracenia flava L. (Sheridan \& Karowe 2000). Among those seeds that manage to survive and germinate, inadequate soil moisture could be an important factor in determining their subsequent survival at this site. The Pine Hills 
population is located within seepage belts high upon slopes. Another population of $S$. rubra ssp. alabamensis that is comparable in size to the Pine Hills population, but has higher seedling densities, occurs at a site that is not managed with fire but is located at the base of a slope with greater soil moisture (J. D. Chesser pers. obs.). Differences in seedling density and survival between the Pine Hills site and this site (hereafter, the wet unmanaged site), therefore, may derive in part from differences in soil moisture, but this hypothesis remains untested. As is the case with $S$. alata, it is possible that factors other than soil moisture (e.g. leaf litter accumulation due to a lack of fire) limit seedling survival in populations of $S$. rubra ssp. alabamensis at the wet unmanaged site.

Specific questions addressed in this study were: (1) What are the current densities of seedlings in the remaining populations of Sarracenia rubra ssp. alabamensis, and how do they vary with respect to fire and soil moisture among sites? (2) Does seed predation/ removal/burial reduce seedling recruitment in this plant and does it differ between a recently burned site and an unburned site? (3) Do seeds stratified and incubated in the laboratory exhibit higher germination rates than those stratified and incubated in the field and between sites? (4) Is seedling survival increased by supplemental soil moisture to a greater extent at a dry, recently burned site than at a wet, unburned site?

\section{MATERIALS AND METHODS}

Seedling densities in several populations of the canebrake pitcher plant. The USFWS provided us with information on, and the location of, 14 populations known to them. Of these, 4 were either extirpated or were declining and contained fewer than 20 clumps and no evidence of seedling recruitment as recently as 2001. These populations were not considered further for visitation. Of the remaining 10 populations, we were able to obtain permission from the landowners and the USFWS to visit 6 . These 6 populations included 5 populations previously described by USFWS as exhibiting juvenile recruitment in 2001. They were censused in late spring of 2007 and 2008 for seedling density. At each site, we exhaustively searched for seedlings within $1 \mathrm{~m}$ of each live clump of adult pitchers we could find. We only found persistent seedlings at 1 site, which contained the second largest population (described in more detail in the following subsection as the wet unmanaged site).

Study sites for experimental investigation of seedling recruitment. We focused our experimental investigations of seedling recruitment on 2 populations for the following reasons: (1) the 2 populations we chose were by far the largest remaining and were large enough to provide adequate sample sizes for our investigations; (2) the populations occurred at sites that differed greatly with respect to hydrology and fire management, 2 factors thought to be vitally important in maintaining population viability in this species (Chesser 2010), and (3) flowering was prolific in both populations, and seedling establishment was documented by the USFWS to have occurred in the past (2001), in contrast to several smaller populations, indicating that both populations were likely large enough to produce viable seeds and seedlings.

The first population, which was the largest remnant population ( 1500 pitchers from $\sim 120$ clumps), was located at the Roberta Case Pine Hills Preserve, (hereafter the dry managed site). Although USFWS records indicate juvenile recruitment in 2001, very few seedlings have been observed at this site since 2003 (Brewer 2005, present study). The dry managed site contained a population that occurs within narrow (10 $\mathrm{m}$ wide) seepage belts on the middle portion of otherwise dry slopes (minimum elevation: $166 \mathrm{~m}$ ), whose overstory was dominated by young longleaf pine Pinus palustris and black jack oak Quercus marilandica. Before restoration treatments began in 2002, several off-site mesophytic trees, including sourwood Oxydendrum arboreum, black gum Nyssa sylvatica, red maple Acer rubrum, sweetbay Magnolia virginiana, and water oak Q. nigra, dominated the midstory. Many of these trees were cut, however, and occurred primarily as stump sprouts in the groundcover along with more or less uniformly high densities of shrubs of hollies and heaths (including Ilex coriacea and I. glabra, Vaccinium darrowii, Gaylussacia mosieri, and Lyonia fruticosa).

The second population ( 800 pitchers from $\sim 50$ clumps) was located in a complex of seepage areas near the base of a slope (minimum elevation $115 \mathrm{~m}$; the wet unmanaged site). This site appeared noticeably wetter and had not been subjected to restoration treatments by 2007, allowing numerous species of mesophytic and floodplain trees (e.g. Ilex opaca, Liquidambar styraciflua) to thrive. Despite being shadier than the dry managed site, the wet unmanaged site contained adult clumps of pitcher plants that tended to be larger on average than those at the dry managed site (Chesser 2010). As with the dry managed site, records from the USFWS indicated the presence of seedlings in 2001 at the wet unmanaged site. Seedlings were more common and abundant, however, at the wet unmanaged site than at the dry managed site in 2007, the year we first began observing the wet unmanaged site.

We verified differences in soil moisture between the dry managed site and the wet unmanaged site by 
measuring soil moisture (\% mass loss upon drying at $40^{\circ} \mathrm{C}$ for $72 \mathrm{~h}$ ) in each seedling plot (described in the next subsection) in March, May, and September 2008 using a $t$-test assuming unequal variances. We assessed temporal variability in soil moisture by calculating the coefficient of variation $(\mathrm{CV})$ for mean soil moisture measurements from March, May, and September.

Seed retention and germination and seedling emergence. To test for seed removal (by predators or secondary dispersal), we established 20 blocks at each of the 2 focal sites. Each block contained a total of 5 plots $(10 \times 10 \mathrm{~m})$. In October and November of 2007, we collected 50 to 60 mature capsules from each of the 2 field sites. In November 2007, corresponding to the time of peak primary seed dispersal from the capsules by wind, we added 100 seeds to each of 4 of the 5 plots in a repeated-measures design. Two hundred seeds from each of 2 capsules were divided evenly into groups of 100. Each group of 100 seeds from each capsule was assigned randomly and added to either a $10 \times 10 \mathrm{~cm}$ seed-retention treatment plot or to an adjacent seedretention control plot. Seeds added to the seed-retention treatment (net treatment) were protected from removal by seed predators and secondary dispersers by overlaying a $10 \times 10 \mathrm{~cm}$ section of netting whose gauge was sufficiently small to preclude seed motility. This netting was secured to the ground using aluminum nails. Net controls were similarly surrounded by aluminum nails, but lacked the netting (Fig. 2). Although the netting was designed to prevent removal, it did not prevent visual loss by burial or loss to decomposition. Therefore, counts of seeds (which occurred in February and March 2008) were underestimates and included only those that we could see on

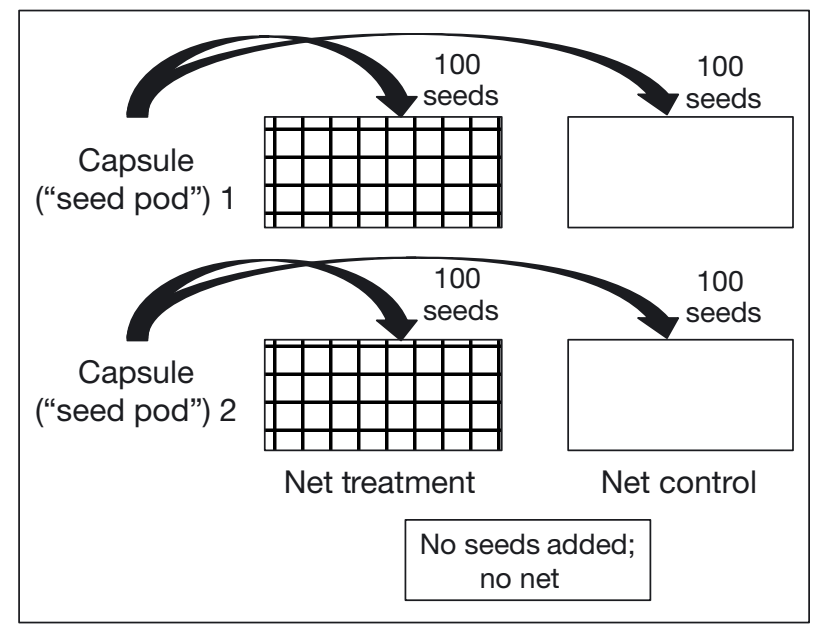

Fig. 2. Experimental design of the seed-retention experiment. $\mathrm{N}=20$ blocks site ${ }^{-1}$; each block contained a total of 5 plots $(10 \times 10 \mathrm{~m})$ the soil surface. We opted not to attempt to recover buried seeds, so as not to disturb the substrate or damage seeds that might be in the process of germinating. Visual loss to burial was accounted for in part by quantifying germination within seed-retention plots. To quantify germination from seeds not added to the net treatment or net controls, we counted seeds and seedlings within a fifth plot to which no seeds were added (no seeds added; no net). We did not establish a netted seed-addition control. Because no seeds or seedlings were observed in the plot to which no seeds were added, all analyses were based on plots to which seeds were added. Previous studies of germination in a related species (Sarracenia alata) showed that netting such as that used in these experiments had negligible effects on soil moisture and thus primarily affected the ability of predators or dispersal agents to remove seeds (J. S. Brewer unpubl. data). Furthermore, although the sheer netting slightly reduced light availability, light is not necessary for seed germination in Sarracenia (Ellison 2001). We examined treatment effects on seed retention using repeated measures analysis of variance, where site was the between-plot effect and the netting treatment was the within-subject or split-plot effect. Seed counts were log transformed to reduce heteroscedasticity. Seedling counts were not normally distributed on account of both the lack of homoscedasticity between treatments at the wet unmanaged site and the lack of germination at the dry managed site. As a result, we used a $Z$-test to test the hypothesis that log seedling density at the wet unmanaged site was significantly greater than 0 and a paired $t$-test to test the hypothesis that log seedling density was greater within netted than within control plots at the wet unmanaged site.

To determine whether moisture contributed to site differences in seedling emergence in May 2008, we examined the correlation between seedling density (number of seedlings to germinate from 100 seeds sown) in netted plots and soil moisture (in March and May 2008) at the wet unmanaged site using simple linear regression. We log-transformed seedling counts to normalize residuals. In addition, the association between seedling density in netted plots in May 2008 and the occurrence of sphagnum moss was analyzed using simple logistic regression. To increase the statistical power of these tests, we first tested to see if seedling counts associated with each of the 2 capsules of origin within each netted plot could be pooled by comparing variance among plots with variance due to capsule origin (calculated as the variance among absolute values of the differences between capsules per plot) using an F-test. We controlled for the effect of sphagnum before doing this test by adding the mean effect of the 
sphagnum on seedling density to observations in plots that lacked sphagnum.

To account for differences in the potential germinability of seeds from each of the 2 populations, we compared germination between the 2 groups in the laboratory using a $t$-test. We randomly sampled 20 seeds from each of 40 capsules randomly sampled from each site. We began stratifying seeds in the laboratory in November 2007, the same time at which we established experimental and control plots in the field. We stratified seeds in Petri dishes at $4^{\circ} \mathrm{C}$ (Ellison 2001) over the winter and attempted to germinate them at $22^{\circ} \mathrm{C}$ in the laboratory in April 2008.

Effects of moisture on seedling survivorship. We manipulated the availability of moisture to seedling transplants in a field experiment to determine whether differences in soil moisture between the dry managed site and the wet unmanaged site contributed to differences in seedling survivorship. We stratified and germinated seeds from both sites in the laboratory (as previously described) and transplanted 400 of the resulting seedlings reciprocally to each site in early May 2008. Prior to transplanting, we submerged the roots of half of the seedlings in a slurry of water-absorbent polymer (Soil Moist ${ }^{\mathrm{TM}}$ Fine Polymer; JRM Chemical) able to hydrate up to 200 times original mass and adhere to the roots of transplants. All seedlings were well watered immediately following transplantation. However, only the roots of seedlings treated with polymer were provided with water released from the granules as the surrounding soil dried. If differences in soil moisture contributed to differences in seedling survivorship between sites, then the polymer treatment should have more effectively prolonged the initial survival of seedlings in drier locations, which we predicted would be more common at the dry managed site regardless of where the seeds originated. We established 20 plots at each site. Ten plots each were chosen at random to receive transplants from 1 of the 2 sources. Within each plot, we transplanted 5 seedlings with the polymer and 5 without. We intended to quantify survivorship (and growth) over the course of the 2008 growing season, but because of dramatic, all-ornone initial effects on survivorship, we analyzed the data after only $2 \mathrm{wk}$, using chi-squared tests of independence, and treating survival of seedlings at each site as a categorical variable. Specifically, we assigned each plot to 1 of 2 mutually exclusive response categories: response $\mathrm{A}$, the number of live seedlings with the polymer $>$ the number of live seedlings without the polymer; response $B$, the number of live seedlings with the polymer $\leq$ the number of live seedlings without the polymer. We predicted that a greater proportion of plots would exhibit response $\mathrm{A}$ at the drier site than at the wetter site.

\section{RESULTS}

Soil moisture measurements averaged over March, May, and September 2008 verified that the dry managed site was significantly drier than the wet unmanaged site $(15.8 \pm 0.9 \mathrm{SE}$ versus $27.2 \pm 0.9 \mathrm{SE} \%$ moisture, 2-tailed $t=5.94, \mathrm{p}<0.0001, \mathrm{df}=49$ ), and that the magnitude of the variation from month to month was greater at the dry managed site $\left(\mathrm{CV}_{\mathrm{dry}}\right.$ managed $=0.172$ versus $\mathrm{CV}_{\text {wet unmanaged }}=0.025$ ).

Netting increased seed retention at both sites in March 2008 ( $p<0.0001$, df $=78$ with block and capsule sources of variation pooled; Fig. $3 ; \mathrm{p}=0.0004$, df $=38$ when block and capsule sources of variation were not pooled). Seed retention/visibility was significantly higher at the dry managed site than at the wet unmanaged site $(\mathrm{p}=0.01 ; \mathrm{df}=78$ when block and capsule sources of variation were pooled; Fig. $3 ; \mathrm{p}=0.02$, df $=$ 39 when block and capsule sources of variation were not pooled). The site $\times$ seed-retention treatment interaction was not significant $(\mathrm{p}=0.52 ; \mathrm{df}=78$ when error variance components were pooled; Fig. $3 ; \mathrm{p}=0.62 ; \mathrm{df}=$ 38 when error variance components were not pooled).

The absolute number of seeds that germinated was significantly lower at the dry managed site than at the wet unmanaged site. There were no seedlings observed at the dry managed site in March or May 2008. In contrast, numbers of seedlings present within both netted plots and controls were significantly greater than $0(Z=$ 2.9 and 3.2, respectively; $\mathrm{p}<0.002$, $\mathrm{df}=39$; Fig. 4 ). Netting had a positive effect on the number of seeds that germinated at the wet unmanaged site (1-tailed paired $t$ $=2.23, \mathrm{p}=0.016 ; \mathrm{df}=39$, Fig. 4). There was no significant effect of seed source or site differences in soil (other than

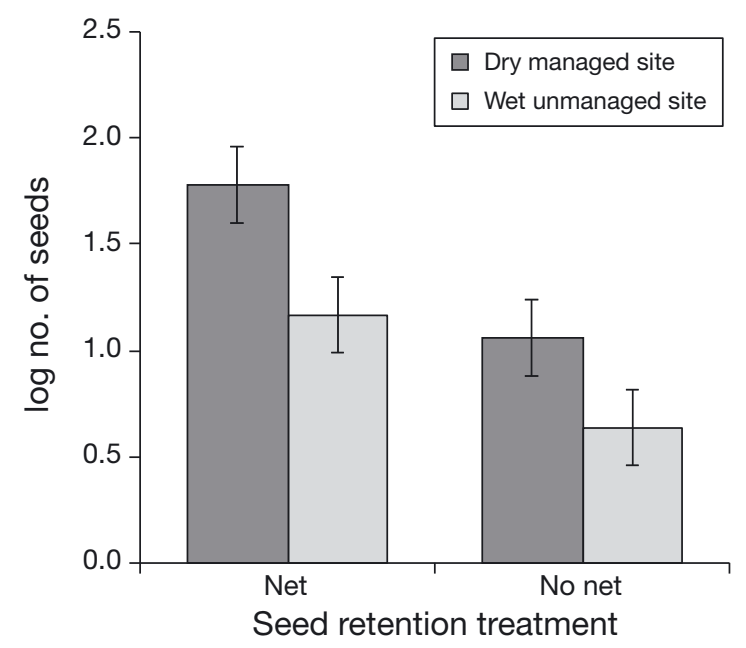

Fig. 3. Sarracenia rubra ssp. alabamensis. Least-squares mean log number of seeds (per 100 seeds sown) retained and observed in March 2008 within the netted and unnetted plots at the 2 sites in which the seed-retention experiment was conducted. Seeds were sown in November 2007. Error bars are $\pm 1 \mathrm{SE}$ 


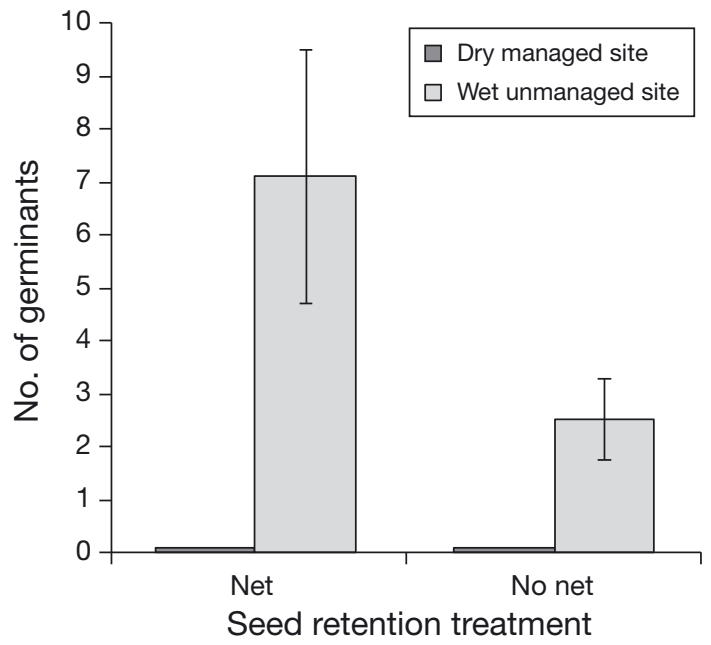

Fig. 4. Sarracenia rubra ssp. alabamensis. Average number of seedlings (per 100 seeds sown) within the netted and unnetted plots at the 2 sites in which the seed-retention experiment was conducted. Seeds were sown in November 2007. Error bars are $\pm 1 \mathrm{SE}$

moisture) on potential germinability, as indicated by roughly equal germinability of seeds stratified and germinated in the laboratory in well-watered soil from each of the 2 sites ( 72 versus $73 \%$ of dry site and wet site seeds, respectively; $\mathrm{p}=0.790, \mathrm{df}=78$ ).

Despite significant differences in soil moisture between the 2 sites, there was no correlation between log seedling density in the net treatment and soil moisture at the wet unmanaged site $\left(\mathrm{r}_{\text {March }}=-0.19, \mathrm{p}=0.43\right.$; $\mathrm{r}_{\text {May }}=-0.21, \mathrm{p}=0.37 ; \mathrm{df}=19$ ). Nevertheless, there was a significant, positive association between the presence of sphagnum moss and seedling density (logistic regression estimate of sphagnum occurrence versus log seedling density $=2.3, \chi^{2}=7.3, \mathrm{p}=0.007, \mathrm{n}=40$; Fig. 5). Linear and logistic regressions were based on the pooled plot and capsule variation. The variance among plots averaged over capsules (after correcting for the effect of sphagnum) was less than the variance of differences between capsules $(F=0.88, \mathrm{n}=40)$.

The survival of transplanted seedlings over a $2 \mathrm{wk}$ period in May 2008 was greater at the wet unmanaged site than at the dry managed site $(100 \%$ of plots with surviving seedlings in untreated controls at the wet unmanaged site versus $15 \%$ at the dry managed site; $\chi^{2}=29.6, \mathrm{p}<0.0001, \mathrm{n}=40$ ). Differences in soil moisture between the sites appeared to be a major cause of site differences in seedling survival. The percentage of plots in which the survival of polymer-treated seedlings was greater than that of untreated seedlings was much higher at the dry managed site than at the wet unmanaged site $(75$ versus $0 \%$ for the dry managed site and the wet unmanaged site, respectively; $\chi^{2}=24, \mathrm{p}<0.0001, \mathrm{n}=40$ ).

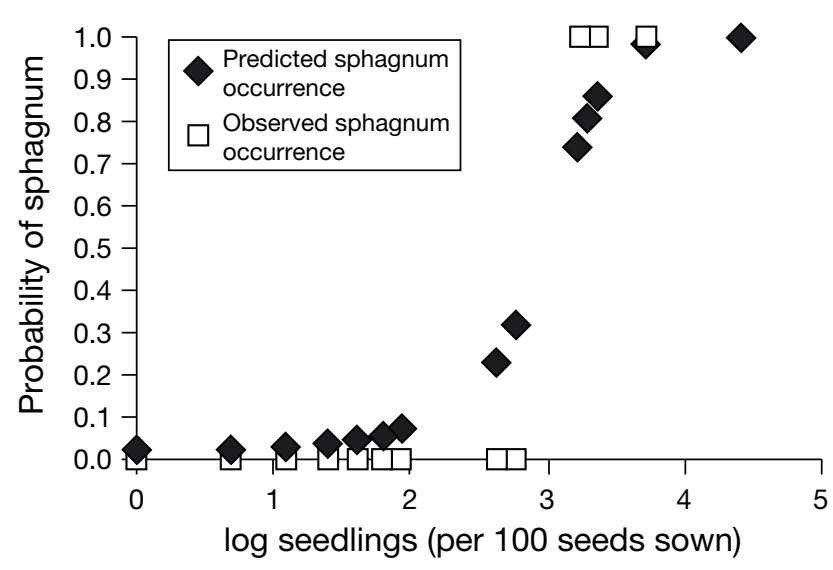

Fig. 5. Logistic regression plot of predicted probability of occurrence of sphagnum $(\downarrow)$ and observed occurrence of sphagnum ( $\square$; position on the $y$-axis indicates observed occurrence, where $0=$ not observed; $1=$ observed) as a function of log seedling density within netted plots at the wet unmanaged site

\section{DISCUSSION}

The results of this research along with those of Brewer (2005) suggest that low soil moisture and the lack of sphagnum moss directly and/or indirectly have greater negative impacts on seedling recruitment in Sarracenia rubra ssp. alabamensis than does fire suppression. This conclusion is based on the facts that (1) seed germination was greater in microsites associated with sphagnum moss, which were relatively common at the wet unmanaged site but largely absent from the dry fire-managed site; and (2) seedling survivorship was significantly hindered by insufficient soil moisture, since soil moisture was lower at the dry fire-managed site than at the wet unmanaged site. We consider each of these 2 factors in order.

Seed germination and emergence were influenced by seed removal and possibly by the provision of moist safe sites by sphagnum moss, with the latter being more important in producing the differences observed between a dry managed site and a wet unmanaged site. Populations from both sites produced viable seeds, and seeds from both locations had an equal likelihood of germinating in soil from either location when germinated in the laboratory under controlled conditions. Despite retaining significantly more seeds per plot among netted treatments, the dry managed site showed no seed germination in plots protected from seed predators or secondary dispersers, whereas the wet unmanaged site had numerous germinants.

Despite significant differences in soil moisture between the 2 sites, the greater rate of seedling emergence at the wet unmanaged site was positively associated with the presence of sphagnum moss but not 
with soil moisture. It is possible that sphagnum moss, which was more abundant at the wet unmanaged site than at the dry managed site, provided moist and thus favorable microhabitat for seed germination while buffering the effects that local microclimate might have on soil moisture. This could in part explain the decoupling of seedling emergence from soil moisture at the wet unmanaged site. Sphagnum moss is generally more abundant at the base of seepage slopes and in swamps than farther up a slope (Drewa et al. 2002, J. S. Brewer pers. obs.). The pitcher plant population at the wet unmanaged site was located at the base of a seepage slope. By contrast, the population at the dry managed site was located in a seepage band situated relatively higher on the slope. Drier soils are likely to have prevented sphagnum from flourishing in those portions of the dry managed site where Sarracenia rubra ssp. alabamensis occurs. Alternatively, it is also possible that sphagnum moss once flourished at the dry managed site in association with the population of $S$. rubra ssp. alabamensis, and was extirpated because it had a lower tolerance of water stress than did adult pitcher plants. This latter explanation could potentially explain the rarity of persistent seedlings at this location.

Differences in soil moisture clearly contributed to differences in seedling survivorship between the dry managed site and the wet unmanaged site. The survival of transplanted seedlings was greater at the wet unmanaged site than at the dry managed site, and seedlings transplanted to the dry managed site benefited from a moisture-absorbing polymer around their roots to a much greater extent than seedlings transplanted to the wet unmanaged site. This experiment was conducted in May 2008, a year after the severe drought of 2007, indicating that site differences in the effect of soil moisture on seedling survival could be exacerbated during years of low rainfall.

The challenges faced by Sarracenia rubra ssp. alabamensis are not unique among rare plant species. Because many rare species have narrow habitat tolerances, few locations are suitable for establishing new populations. Further, because many populations are very small, they may lack the genetic variation necessary to adapt to the challenges they could face in the future, whether these result from changing climate or from migrations to habitat other than that in which they originally evolved due to the anthropogenic destruction of the original habitat. Although models suggest that both populations of S. rubra ssp. alabamensis should be able to persist for several decades by means of ramet survival and vegetative reproduction (Chesser 2010), colonization, the rescue effect, and adaptation facilitated by sexual reproduction all depend on successful seedling establishment (Felsen- stein 1974, Maynard Smith 1978, Barton \& Post 1986, Menges 1990, Winkler \& Fischer 2001, Agrawal 2006, Ellis et al. 2007). If continued climate change makes the currently occupied ranges of these species unsuitable, then those that are not capable of migrating or adapting will go extinct. This presents particular challenges to conservationists, because the vulnerability of seedlings to environmental factors that would not have as dramatic an effect on adults (e.g. dry soils) makes the success of re-introduced populations unpredictable, even in the event that such populations can be established with adults cultivated ex situ. On the other hand, the long life span of perennials such as $S$. rubra spp. alabamensis, combined with the fact that short-term population viability is relatively insensitive to the seedling recruitment failure (Brewer 2001, Ellis et al. 2007, Chesser 2010), might provide sufficient time for conservation biologists to investigate ways of artificially increasing seedling recruitment and thus long-term metapopulation viability.

Acknowledgements. We thank D. Reed, L. McCook, M. Holland, and A. Fisher-Wirth for suggestions in performing this work as well as The Nature Conservancy for allowing access to the study sites. The comments of 2 anonymous reviewers greatly improved the manuscript. This work was funded by grants from the US Fish and Wildlife Service and the Birmingham Audubon Society.

\section{LITERATURE CITED}

Agrawal AF (2006) Similarity selection and the evolution of sex: revisiting the Red Queen. PLoS Biol 4:e265

Barker NG, Williamson GB (1988) Effects of a winter fire on Sarracenia alata and S. psittacina. Am J Bot 75:138-143

Barton NH, Post RJ (1986) Sibling competition and the advantage of mixed families. J Theor Biol 120:381-387

Brewer JS (1999) Effects of fire, competition, and soil disturbances on regeneration of a carnivorous plant (Drosera capillaris). Am Midl Nat 141:28-42

Brewer JS (2001) A demographic analysis of fire-stimulated seedling establishment of Sarracenia alata (Sarraceniaceae). Am J Bot 88:1250-1257

> Brewer JS (2005) The lack of favorable responses of an endangered pitcher plant to habitat restoration. Restor Ecol 13:710-717

Brewer JS, Platt WJ (1994) The effects of fire season and herbivory on reproductive success of a clonal forb, Pityopsis graminifolia. J Ecol 82:665-675

Brewer JS, Cunningham AL, Moore TP, Brooks RM, Waldrup JL (2009) A six-year study of fire-stimulated flowering cues and coexistence of two perennial grasses in a wet longleaf pine (Pinus palustris) savanna. Plant Ecol 200: 141-154

> Carrington ME (1999) Post-fire seedling establishment in Florida sand pine scrub. J Veg Sci 10:403-412

Case FW, Case RB (1974) Sarracenia alabamensis, a newly recognized species from central Alabama. Rhodora 76: 650-665

Chesser JD (2010) Causes of site differences in seedling recruitment and population dynamics in the critically 
endangered pitcher plant, Sarracenia rubra ssp. alabamensis. $\mathrm{PhD}$ dissertation, University of Mississippi, Oxford, MS

> Christensen NL, Muller CH (1975) Effects of fire on factors controlling plant growth in Adenostoma chaparral. Ecol Monogr 45:29-55

Denham AJ (2008) Seed predation limits post-fire recruitment in the waratah (Telopea speciosissima). Plant Ecol 199:9-19

Drewa PB, Platt WJ, Moser EB (2002) Community structure along elevation gradients in headwaters of longleaf pine savannas. Plant Ecol 160:61-72

Ellis MM, Weekley CW, Menges ES (2007) Evaluating stability in Ziziphus celata, a highly endangered clonal shrub endemic to Lake Wales Ridge, central Florida. Endang Species Res 3:125-132

Ellison AM (2001) Interspecific and intraspecific variation in seed size and germination requirements of Sarracenia (Sarraceniaceae). Am J Bot 88:429-437

Felsenstein J (1974) The evolutionary advantage of recombination. Genetics 78:737-756

Harper JL (1977) Population biology of plants. Academic Press, London

Harper RM (1922) Some pine barren bogs in central Alabama. Torreya 22:57-60

Keeley JE (1991) Seed germination and life history syndromes in the California chaparral. Bot Rev 57:81-116

Kirkman K, Drew MB, Edwards D (1998) Effects of experimental fire regimes on the population dynamics of Schwalbea americana. Plant Ecol 137:115-137

Lamont BB, Witkowski ETF, Enright NJ (1993) Post-fire litter microsites - safe for seeds, unsafe for seedlings. Ecology 74:501-512

Editorial responsibility: Dave Roberts,

Canterbury, UK
Lesica P (1999) Effects of fire on the demography of the endangered geophytic herb, Silene spaldingii (Caryophyllaceae). Am J Bot 86:996-1002

Maynard Smith J (1978) The evolution of sex. Cambridge University Press, Cambridge

- Menges ES (1990) Population viability analysis for an endangered plant. Conserv Biol 4:52-62

Menges ES (1995) Factors limiting fecundity and germination in small populations of Silene regia, a rare hummingbirdpollinated forb. Am Midl Nat 133:242-255

O'Dowd DJ, Gill AM (1984) Predator satiation and site alteration following fire: mass reproduction of alpine ash (Eucalyptus delegatensis) in southeastern Australia. Ecology 65:1052-1066

Schnell DE (2002) Carnivorous plants of the United States and Canada, 2nd edn. Timber Press, Portland, OR

Sheridan PM, Karowe DN (2000) Inbreeding, outbreeding, and heterosis in the yellow pitcher plant, Sarracenia flava (Sarraceniaceae), in Virginia. Am J Bot 87:1628-1633

US Fish and Wildlife Service (USFWS) (1992) Agency draft Alabama canebrake pitcher plant recovery plan. USFWS, Jackson, MS. Fed Reg 54:10150-10154

Winkler E, Fischer M (2001) The role of vegetative spread and seed dispersal for optimal life histories of clonal plants: a simulation study. Evol Ecol 15:281-301

Zammit C, Westoby M (1987) Seedling recruitment strategies in obligate-seeding and resprouting Banksia shrubs. Ecology 68:1984-1992

> Zammit C, Westoby M (1988) Pre-dispersal seed losses and the survival of seeds and seedlings of two serotinous Banksia shrubs in burnt and unburnt heath. J Ecol 76: 200-214

Submitted: May 25, 2010; Accepted: December 15, 2010 Proofs received from author(s): March 1, 2011 